\title{
PENHORA DE QUOTAS POR DÍVIDA PARTICULAR DE SÓCIO: EVOLUÇÃO HISTÓRICO-LEGISLATIVA E JURISPRUDENCIAL
}

\author{
THE SEIZURE OF SHARES DUE TO SHAREHOLDER'S PERSONAL DEBT: A \\ HISTORICAL STUDY OF THE EVOLUTION OF THE LEGAL TREATMENT AND \\ CASE LAW TOWARDS THE INSTITUTE
}

${ }^{1}$ Alexandre Ferreira de Assumpção Alves

${ }^{2}$ Matheus Sousa Ramalho

\section{RESUMO}

Análise histórica do tratamento legislativo da penhora de quotas por dívidas de sócio e repercussão na affectio societatis. Utiliza-se o método dedutivo partindo-se de regras e princípios reconhecidos como verdadeiros e estabelecer relações com uma segunda proposição para, a partir de raciocínio lógico, chegar à verdade daquilo que propõe. Com base na pesquisa bibliográfica e documental, pretende-se demonstrar como a possibilidade de penhora das quotas do sócio, não autorizada pelo art. 292 do Código Comercial, evoluiu com as sociedades por quotas de responsabilidade limitada, a ponto de a legislação hodierna admitir a penhora das quotas independente de permissivo contratual.

PALAVRAS-CHAVE: Sociedade; Penhora; Quotas; Sócio; Credor; Affectio Societatis

\begin{abstract}
Historical analysis of the legal treatment of the seizure of shares due to shareholder's personal debt and the impacts of such measure on the affectio societatis. In order to do so, with the usage of the deductive method of research, hereby it will be presenting two different views on the issue: a first one based solemnly on the rules and principles the are commonly accepted and a second based on logical arguments. Afterwards, the two premises are going to be confronted in order achieve the best answers. Moreover, with the usage of bibliographical and documental research, this work intends to demonstrate how the seizure of shares has evolved from an impossibility, under the terms of the article 292 of the Commercial Code, to a reality, whereas the seizure is now possible even on those cases where the article of association lacks the regulation on the issue.
\end{abstract}

KEYWORDS: Corporations; Seizure; Shares; Shareholder; Affectio Societatis

\footnotetext{
${ }^{1}$ Professor Associado de Direito Comercial na Universidade Federal do Rio de Janeiro - UFRJ e na Universidade do Estado do Rio de Janeiro - UERJ, Rio de Janeiro, RJ, (Brasil). Membro do PPDG da UERJ, na linha Empresa e Atividades Econômicas, Rio de Janeiro, RJ, (Brasil). E-mail: asaa@ uol.com.br.

${ }^{2}$ Advogado. Mestre em Direito pela Universidade do Estado do Rio de Janeiro - UERJ, Rio de Janeiro, RJ, (Brasil). Expositor em Direito Empresarial na Escola da Magistratura - EMERJ, Rio de Janeiro, RJ, (Brasil). E-mail: mattsr1109@gmail.com.
} 


\section{INTRODUÇÃO}

O trabalho se propõe a analisar, a partir da perspectiva histórica, o tratamento legislativo da penhora de quotas por dívidas de sócio, com enfoque na evolução do tema na doutrina e na jurisprudência brasileira dos tribunais superiores desde o advento do Código Comercial. Utiliza-se o método dedutivo partindo-se de regras e princípios reconhecidos como verdadeiros (premissa maior) para estabelecer relações com uma segunda proposição (premissa menor) para, a partir de raciocínio lógico, chegar à verdade daquilo que propõe (conclusão). Com apoio na pesquisa dos tipos bibliográfica e documental, pretende-se demonstrar como a possibilidade de penhora das quotas do sócio, considerada não autorizada pelo art. 292 do Código Comercial, evoluiu no pensamento doutrinário a partir da disciplina das sociedades por quotas de responsabilidade limitada, a ponto de se admitir hodiernamente a livre penhora das quotas, independente de permissivo contratual e da affectio societatis entre os sócios.

Serão analisadas decisões paradigmas do Supremo Tribunal Federal e, posteriormente, do Superior Tribunal de Justiça, que sempre estiveram atreladas a um marco teórico, seja no sentido da impenhorabilidade da quota decorrente de cláusula contratual ou para reputá-la como bem móvel com individualidade própria, distinto do capital e passível de constrição.

Ao se perscrutar a legislação realiza-se o cotejo do Código de Processo Civil de 1939 com o Código de 1973 e a repercussão na interpretação dos novos dispositivos desse diploma na admissibilidade de penhora da quota. Examinam-se as mudanças promovidas pelo Código Civil de 2002 e sua aplicação às sociedades personificadas e não personificadas, pela Lei n. 11.382/2006 e, por fim, pelo atual Código de Processo Civil, vigente desde 18 de março de 2016, a partir da comparação com o CPC revogado, destacando suas inovações e avanços.

\section{A IMPENHORABILIDADE DAS QUOTAS POR DÍVIDAS DO SÓCIO SOB A ÉGIDE DO CÓDIGO COMERCIAL E DA LEGISLAÇÃO PROCESSUAL DA ÉPOCA (DECRETO N. 737/1850 E DECRETO-LEI N. 1.608/39)}

A possibilidade de penhora de quotas do capital da sociedade pelos credores sociais nunca foi questionada pela doutrina ou na jurisprudência, em razão da capacidade da pessoa jurídica para o exercício de direitos e assunção de obrigações ${ }^{3}$. A autonomia patrimonial decorrente da aquisição

\footnotetext{
${ }^{3}$ Cf. Art. 1.022 do Código Civil: A sociedade adquire direitos, assume obrigações e procede judicialmente, por meio de administradores com poderes especiais, ou, não os havendo, por intermédio de qualquer administrador.
} 
da personalidade jurídica confere à sociedade o dever de honrar seus compromissos perante os credores e, em caso de insucesso, as quotas - por integrarem o patrimônio social - devem servir ao pagamento. Ao contrário, a possibilidade de penhora de quotas para satisfazer os credores particulares de sócio é um dos temas mais instigantes no direito societário e onde se verificou importante evolução do princípio da affectio societatis para permitir a entrada de estranho na sociedade, mesmo forçada.

Para demonstrar tal evolução de pensamento, o trabalho adota como marco teórico a doutrina de José Xavier Carvalho de Mendonça (1933) - influenciada pela doutrina francesa da época - de que as quotas só poderiam ser penhoradas após liquidados os bens sociais e pagos os credores.

Os sócios na constituição de uma sociedade, exceto cooperativa, devem fixar no ato constitutivo o valor do capital em moeda nacional, considerado seu "fundo originário e essencial", para que a sociedade possa realizar os atos e operações. Tal valor pode ser modificado, observadas as disposições de lei, durante a existência da sociedade. O capital, posto que integre o patrimônio social, não se iguala a esse, pois o patrimônio abrange os créditos, bens, lucros, reservas e obrigações (dívidas, inclusive perante os sócios) assumidas pela sociedade.

José Xavier Carvalho de Mendonça (Idem, p. 29) explica que “o fundo social é o patrimônio da sociedade no sentido econômico, a dizer, a soma de todos os bens que podem ser objeto de troca, possuído pela sociedade; compreende não somente o capital social, como tudo que a sociedade adquirir e possuir durante a sua existência".

O capital social é dividido em quotas ou ações, conforme o tipo da sociedade. Advirta-se, de plano, o tradicional consenso sobre a possibilidade de penhora da ação por dívida do acionista sob a justificativa de se tratar de título negociável sem prévia autorização dos demais acionistas ${ }^{4}$. Ao contrário, para penhora de quotas o pensamento doutrinário era baseado no art. 292, $1^{\text {a }}$ alínea, do Código Comercial ${ }^{5}$ e na compreensão da expressão "fundos líquidos".

\footnotetext{
${ }^{4}$ A premissa tem por base o art. 297 do Código Comercial, segundo o qual as ações podem ser exaradas em forma de título ao portador, ou por inscrições nos registros da companhia: no primeiro caso opera-se a transferência por via de endosso: no segundo só pode operar-se por ato lançado nos mesmos registros com assinatura do proprietário ou de procurador com poderes especiais; salvo o caso de execução judicial. Tal negociação, expressamente prevista no Código e nas leis posteriores, sustenta a admissibilidade de penhora, pois não haveria necessidade do consentimento dos acionistas para a alienação.

${ }^{5}$ Art. 292. O credor particular de um sócio só pode executar os fundos líquidos que o devedor possuir na companhia ou sociedade, não tendo este outros bens desembargados, ou se, depois de executados, os que tiver não forem suficientes para o pagamento. Corroborando a disposição do art. 292, o art. 530, § 6º do Decreto n. 737/1850 e o art. 270, alínea "e" do Decreto n. 848/1890, ao disporem sobre a penhora nos processos comerciais, admitiam serem penhoráveis, "não havendo absolutamente outros bens, os fundos líquidos que o executado possuir na companhia ou sociedade comercial a
} 
O art. 292 estabelecia uma prioridade de excussão dos bens particulares do sócio para a satisfação de seus credores. A primazia deveria recair sobre os bens "desembargados" e, subsidiariamente, nos "fundos líquidos". Objetivamente pode-se afirmar que a expressão "fundos líquidos" se referia à parte do patrimônio líquido da sociedade que restar após a satisfação dos credores sociais, valor apurado após a liquidação ordinária (pelos próprios sócios) ou judicial, ou ainda na apuração de haveres em favor do credor, se a sociedade não estivesse em dissolução. Essa última hipótese era bastante discutível caso não houvesse previsão no contrato, pois o Código Comercial sobre ela silenciava ${ }^{6}$. A mesma primazia se estendia aos credores sociais em caso de falência do sócio, pois a "quota líquida" do falido somente poderia ser arrecadada depois de satisfeitos previamente os credores da sociedade solvente. Comentando o artigo 292, José Xavier Carvalho de Mendonça (Idem, p. 71) pôs em relevo o direito patrimonial do sócio em relação à sociedade.

Parece-nos que o direito de sócio, isto é, a posição jurídica dos sócios nas sociedades
comerciais, analisa-se em duas partes: um direito patrimonial e outro pessoal. O direito
patrimonial é o direito de crédito consistente [...] b) em participar na partilha da massa
resídua, depois de liquidada a sociedade. Este direito de crédito é, como se vê,
condicionado, podendo ser exercido somente sobre os lucros líquidos, partilháveis
conforme os termos do contrato social, e sobre o ativo líquido, a dizer, sobre o saldo
verificado depois da liquidação. Os sócios, sob qualquer pretexto, não concorrem com os
credores da sociedade; têm um direito de crédito subordinado inteiramente à liquidação
social, de modo que este poderá ser igual a zero ou ainda descer abaixo de zero, tornando-
se quantidade negativa, passivo.

Embora o sócio seja titular de quota ou quotas, ele não tem direito de propriedade sobre o "fundo social", ou seja, o patrimônio da sociedade, mas apenas um direito de crédito, ainda assim condicionado ao resultado positivo da liquidação, a ensejar a partilha do remanescente. Após a conferência do capital social através da subscrição das quotas, essas se "desintegram" do patrimônio do sócio para integrar o patrimônio da sociedade, consectário do princípio do universitas distat a singulis. Ao sócio, portanto, não seria lícito dispor da quota, donde se conclui sua impenhorabilidade.

que pertencer. " Como a quota social não é considerada bem integrante desse fundo líquido, por ser fração do capital e esse ser destinado precipuamente ao pagamento dos credores sociais, a dedução era em prol da sua impenhorabilidade.

6 Antônio Bento de Faria, ex-ministro e presidente do Supremo Tribunal Federal, apoiado na doutrina de Jean Lépargneur e Charles-Léon Lyon-Caen e Louis Renault, defende a liberdade de se fixar no contrato as condições de cessão de quotas, respeitadas as condições estabelecidas por lei (Direito Comercial - Parte Primeira. Rio de Janeiro: A. Coelho Branco Editor, 1948, v. 2, p. 406) 
Percebe-se que o autor, quando arrola os bens passíveis de penhora para os fins do art. 292, sustenta a impenhorabilidade das quotas ${ }^{7}$ enquanto não se encerrar o pagamento aos credores na liquidação da sociedade e apurado o "fundo líquido"

Por fundos líquidos cuja penhora a lei permite, entendem-se

a) os saldos à disposição do sócio, sendo considerado dinheiro do executado em mãos de terceiro (sociedade) [refere-se o autor aos lucros ainda não pagos]. A penhora nesse caso só se efetua se a sociedade, por seu sócio gerente, confessar que realmente existem esses saldos.

b) a parte ou quota apurada na liquidação da sociedade e partilhada ao sócio devedor. ${ }^{8}$

A tese da impenhorabilidade da quota estimulava a transferência de bens do patrimônio particular do sócio para a sociedade, colocando os credores particulares numa posição de inferioridade ou "subserviência" aos credores desta. O legislador pretendeu estimular a atividade social e garantir primordialmente aos credores sociais a solução do crédito, relegando a segundo plano a atividade desenvolvida pelos sócios e os compromissos por eles firmados com terceiros.

Antônio Bento de Faria (1948, p.190) associa a impenhorabilidade da quota enquanto não se dissolver a sociedade e ultimar sua liquidação ao caráter intuitu personae das sociedades "por quotas", ao contrário das sociedades "por ações". Para o jurista "o caráter pessoal da sociedade não permite que o seu patrimônio passa ser molestado pela ação dos credores particulares de seus sócios", exsurgindo a preocupação com a manutenção da affectio societatis.

A insuscetibilidade de penhora das quotas durante a vigência da Parte Primeira do Código Comercial $^{9}$ estava associada à cessão a terceiros ou instituição de condomínio sobre a quota, hipóteses em que era necessário o consentimento dos sócios, nos termos do art. 334. Nota-se, nesse ponto, uma mudança sensível de paradigma do Código Comercial em cotejo com a disciplina atual da penhora de quotas de sociedades do tipo simples e de tipos de sociedades empresárias aos quais se aplica o mesmo regime. A legislação também condiciona a eficácia da cessão, total ou parcial, da quota ao consentimento dos demais sócios (art. 1.003 do Código Civil), mas não veda a penhora.

O Decreto-lei n. 1.608/1939, instituiu um novo Código de Processo Civil, deixando de vigorar as disposições do Decreto n. 737/1850 em razão da extinção do processo comercial (art. $1^{\circ}$ ).

\footnotetext{
${ }^{7} \mathrm{O}$ autor conclui que como o "credor do sócio não pode penhorar os bens sociais por dívidas particulares de seu devedor", a quota, como bem social integrante do capital, era absolutamente impenhorável por ser inalienável, apoiando-se no art. 529, $\S 1^{\circ}$, do Decreto n. 737/1850 (idem, p.106). Ao contrário, as ações poderiam ser penhoradas por dívidas de seus titulares (idem, p.107).

${ }^{8}$ Ibidem.

${ }^{9} \mathrm{O}$ art. 2.045 do C.Civil revogou toda a Parte Primeira do Cód. Comercial (arts. $1^{\circ}$ a 456), tornando insubsistente a referência aos arts. 292 e 334. A penhora de quotas e ações é admitida, hoje, no art. 835, IX do CPC.
} 
O advento da novel legislação não alterou o entendimento anterior, pois a orientação do art. 292 do Código Comercial foi expressamente mantida ${ }^{10}$.

Diante do teor do art. 292, corroborado pela legislação processual vigente, não havia margem para sustentar a penhora da quota para que o credor particular pudesse fazer recair a execução sobre ela em detrimento dos credores sociais, ou ainda quando a sociedade não estivesse em dissolução. Sem embargo, o tema ganha novas nuances nas sociedades por quotas de responsabilidade limitada, disciplinadas em diploma especial - o Decreto n. 3.708, de 10 de janeiro de 1919.

\section{A PENHORABILIDADE DA QUOTA DE SOCIEDADE POR QUOTAS DE RESPONSABILIDADE LIMITADA}

A sociedade por quotas de responsabilidade limitada foi introduzida pelo Decreto n. 3.708, de 10 de janeiro de 1919, portanto não se encontrava disciplinada no Código Comercial. Tal constatação é importante para o exame da possibilidade de penhora de quotas por dívidas do sócio. Diante da previsão da sociedade por quotas em lei especial seria possível afastar o artigo 292 do Código Comercial para admitir que a quota pudesse ser penhorada? A resposta não era fácil diante do laconismo do Decreto sobre o tema e das disposições dos artigos $2^{\circ}$ e 18.

O Decreto determinava que fossem observadas as disposições do Código Comercial quanto aos requisitos do contrato, mas também dispunha que se observasse supletivamente ao contrato as disposições da lei das sociedades anônimas, desde que compatíveis com ele. Diante das disposições dos arts. $2^{\circ}$ e art. 18 qual diploma seria aplicado supletivamente ao Decreto n. 3.708/19?

Considerando-se que a sociedade por quotas reunia características personalistas como a exclusividade da administração por sócio e a solidariedade pela integralização do capital em caso de falência, a doutrina majoritária da época, capitaneada por Waldemar Ferreira (1961, p. 123) ${ }^{11}$,

\footnotetext{
${ }^{10}$ É a ilação que se tem com a leitura e interpretação sistemática dos arts. 930, 931 e 942, XII, in verbis: Art. 930. A penhora poderá recair em quaisquer bens do executado, na seguinte ordem: [...] V - direitos e ações. Art. 931. Consideram-se direitos e ações, para os efeitos de penhora: as dividas ativas, vencidas, ou vincendas, constantes de documentos; as ações reais, reipersecutórias, ou pessoais para cobrança de dívida; as quotas de herança em autos de inventário e partilha e os fundos líquidos que possua o executado em sociedade comercial ou civil. [grifos nossos]

Art. 942. Não poderão absolutamente ser penhorados: [...]

XII- os fundos sociais, pelas dívidas particulares do sócio, não compreendendo a isenção os lucros líquidos verificados em balanço.

${ }^{11}$ No mesmo sentido Carlos Fulgêncio da Cunha Peixoto afirmou ser evidente que a sociedade por quotas era uma sociedade de pessoas, pois a ressalva do art. 18 do Decreto n. 3.708/19 ("na parte aplicável") afasta a aplicação completa da lei das sociedades anônimas, o que não ocorreria se a sociedade fosse de capital. Entretanto, o jurista admite que o contrato possa conter cláusula autorizando a alienação das quotas a estranhos ao quadro social,
} 
sustentava tratar-se de sociedade de pessoas, sendo o Código Comercial aplicável nas omissões do Decreto n. 3.708/19 e não a lei das sociedades anônimas. Para esta corrente somente seria possível a penhora da quota com o consentimento de todos os sócios, por aplicação supletiva do art. 334 do Código Comercial. Por se tratar de sociedade de pessoas não se admitia que o credor particular do sócio pudesse vir a integrar o quadro social caso a quota lhe fosse adjudicada ou arrematada por terceiro. Tal ingresso "compulsório" desnaturaria a sociedade e violaria a affectio societatis.

Em sentido contrário, João Eunápio Borges (1967, p. 326-7) defendia o particularismo da sociedade por quotas apoiado nas características que lhe atribuiu o legislador e no art. 18 do Decreto. $\mathrm{O}$ autor incluiu a sociedade como sociedade de capital, ao lado das sociedades anônimas, sustentando:

\begin{abstract}
A sociedade por cotas de responsabilidade limitada não se confunde com nenhum dos outros tipos de sociedade, nem se reduz à subespécie de qualquer delas. Tem, ao contrário, fisionomia jurídica e função econômica próprias que lhe asseguram posição definida e peculiar entre as suas coirmãs mais velhas que, com exceção da anônima, estão sendo banidas por ela da vida mercantil.
\end{abstract}

Diante da omissão no Decreto n. 3.708 sobre a penhora de quotas seria possível admiti-la? Independentemente da divergência quanto a resposta, é certo que a legislação processual vigente à época (Decreto n. 737) e a posterior (CPC de 1939), como já mencionado, somente admitiam a penhora dos fundos líquidos, em consonância com o art. 292 do Código Comercial. Assim sendo, não se poderia extrair do Decreto uma conclusão segura quanto a possibilidade de penhora.

João Eunápio Borges (Idem, p. 345-6) discorda da conclusão acima. Segundo ele

Não se estende às quotas [de sociedade por quotas] o princípio consagrado no art. 292 do
Código Comercial que só admite penhore o credor os fundos líquidos que o devedor possuir
na sociedade, e não a sua parte, o seu quinhão social. [...] Mas, não constitui a quota
simples expressão numérica de parte ideal de um capital ou patrimônio. Representa ela, ao
contrário do que se dá nas demais sociedades, uma fração determinada daquele patrimônio,
tendo individualidade própria, existência distinta do todo e das demais partes em que este
se divide. É suscetível de transferências, por ato entre vivos ou causa mortis, a própria
sociedade pode adquiri-las e revende-la em seguida, como coisa determinada, entidade a se,
inconfundível com as demais cotas. E nenhum obstáculo existe, nas leis que lhe são
aplicáveis [referindo-se implicitamente ao Decreto n. 3.708 e ao Decreto-Lei n.
2.627/1940], à expedição pela sociedade - como se dá com as ações nominativas - de
certificados de títulos nominativos representativos das cotas. [grifos nossos].

Ressalva o autor que a penhora da quota poderá ser vedada "se o contrato proibir a cessão das cotas, segue-se que elas são inalienáveis, não podendo ser apenhadas nem penhoradas, a não ser

independentemente de autorização dos demais sócios, afastando a incidência do art. 334 do Código Comercial, caso em que a penhora seria lícita (As Sociedades por Quotas de Responsabilidade Limitada. Rio de Janeiro: Forense, $1956, \mathrm{v}$. 1, p.60). 
com o consentimento dos sócios” (Idem, p. 346). Na omissão do contrato deveria ser aplicável a lei das sociedades anônimas, por força do art. 18.

Com o argumento de que a quota tem existência distinta dentro do patrimônio da sociedade, ou mesmo do capital da qual é fração, João Eunápio Borges procura implicitamente afastar a tese de José Xavier Carvalho de Mendonça de que o sócio não tem direito sobre a quota, devendo ser observada a ordem do art. 292 do Código Comercial. Atribuída à quota a natureza de bem móvel, presumidamente alienável e integrante do patrimônio do sócio, separando-a da noção de "fundo social", ficaria também afastada a incidência do art. 942, XII, do CPC de 1939.

Diante da controvérsia na doutrina pelo laconismo do Decreto n. 3.708 quanto a penhora da quota, como o Supremo Tribunal Federal se posicionou ao examinar processos em que se discutiu o tema? Qual das doutrinas aqui expostas foi acatada? A promulgação de um novo Código de Processo Civil, em 1973, alterou o entendimento jurisprudencial anterior? São questões que se expõe adiante.

\section{PANORAMA DA JURISPRUDÊNCIA DO SUPREMO TRIBUNAL FEDERAL ANTES E APÓS O ADVENTO DO CÓDIGO DE PROCESSO CIVIL DE 1973}

A pesquisa realizada nos acórdãos do STF na vigência do CPC de 1939 sobre a possibilidade de penhora por dívidas de sócio revelou que, na maioria das decisões, os ministros acataram a tese da impenhorabilidade. Em face das limitações do texto pelas normas editoriais para publicação desse artigo, os autores centraram a análise nas decisões paradigmas, informando em nota de rodapé as demais decisões que trataram do tema ${ }^{12}$.

Em 1947, no julgamento do Recurso Extraordinário n. 6.639/SP, os ministros da Segunda Turma acolheram o voto do relator ministro Orosimbo Nonato e não conheceram do recurso ${ }^{13}$. A

\footnotetext{
12 No julgamento do RE 34.680/RS, Relator Min. Nelson Hungria, em 27/01/1958 (In DJ de 29/05/1958), a Primeira Turma do STF proclamou a impenhorabilidade da quota diante da cláusula contratual que proibia sua cessão a terceiros sem o consentimento dos sócios. O acórdão, considerou ser possível o contrato retirar a negociabilidade da quota e, por conseguinte, torna-la impenhorável. Os ministros adotaram a mesma referência de análise do RE 24118/SP (a seguir comentado) e o marco teórico na doutrina de João Eunápio Borges, ou seja, é presumida a possibilidade de penhora da quota por dívida do sócio, salvo se o contrato contiver cláusula restritiva, situação fática em que se apoiaram os ministros para decidir.

A tese de impenhorabilidade da quota, por não ser fundo líquido, apoiada na doutrina de Carvalho de Mendonça e nos arts. 292 do C.Com e 942, XII, do CPC39, motivou os acórdãos nos RE 47275/BA (Primeira Turma e Tribunal Pleno) e RE 75680/GO (Primeira Turma).

${ }^{13}$ BRASIL. Supremo Tribunal Federal. Segunda Turma, Recurso Extraordinário 6.639/SP. Relator Min. Orosimbo Nonato. Julgamento em 09/07/1947. Disponível on line em http://redir.stf.jus.br/paginadorpub/paginador.jsp?docTP=AC\&docID=506059
} 
Turma considerou que o recorrente não trouxe argumentos capazes de refutar a doutrina da época, que considerava a quota impenhorável em face das disposições do Código Comercial e do CPC 39, não tendo esse diploma revogado o art. 292 do Código Comercial. O relator encontrou supedâneo para seu voto na doutrina de José Xavier Carvalho de Mendonça, Waldemar Ferreira e Amílcar de Castro, sendo que esse se louvou dos argumentos do primeiro jurista.

Causou repercussão ${ }^{14}$ à época de seu julgamento, em 1953, o acórdão proferido no Recurso Extraordinário n. 24.118/SP por divergir da orientação anterior no $\mathrm{STF}^{15}$. O relator Nelson Hungria admitiu a penhora e adotou como fundamentos para seu voto: (i) o fato de o Decreto n. 3.708/19 não cuidar da transferência das quotas, devendo ser observada a lei das sociedades anônimas, por força do art. 18 do primeiro diploma; (ii) a aplicação do art. 127, § $1^{\circ}$, do Decreto-lei n. 2.627 (lei das sociedades por ações vigente), que autorizava a transferência de ações mediante registro da operação em livro próprio; (iii) o caráter personalista da sociedade limitada não impede a penhora da quota por inexistir restrição na legislação do tipo societário, portanto afastou a incidência do art. 292 do Código Comercial; (iv) a penhora da quota não implica penhora de fundos líquidos do sócio e sim na penhora do "direito" de sócio, numa clara analogia à ação; (v) salvo se houver proibição à cessão de quotas a estranhos no contrato é que estará prejudicada a penhora, pois o que é alienável é penhorável.

Ao final de seu voto, o relator declarou que como efeito da penhora o credor exequente passa a ostentar a condição de sócio, com os ônus e vantagens decorrentes. A Turma acompanhou o relator pelo não conhecimento do recurso pela ausência de violação da decisão recorrida à legislação federal.

O acórdão corroborou o entendimento de João Eunápio Borges sobre o tema, mas esse jurista sustenta que a sociedade por quotas se trata de uma sociedade de capitais, enquanto que o ministro relator a considerou não ser "somente de capital, pois nela não deixa de influir o intuitu personae."

\footnotetext{
Acesso em 24/7/2016. Ementa: Art. 292, n. II, do Cod. de Proc. Civil. Art. 942, n. XII do mesmo Código. Fundos sociais. Quotas de sócios. Art. 292 do Cod. Do Comércio.

${ }^{14}$ Waldemar Ferreira (1961, p. 446) e Rubens Requião (2014, p. 603-4) criticaram duramente a decisão e a equiparação da quota às ações de sociedades por ações e a consideração de ser a lei das S/A supletiva ao Decreto n. 3.708/1919.

${ }^{15}$ BRASIL. Supremo Tribunal Federal. Primeira Turma, Recurso Extraordinário 24.118/SP. Relator Min. Nelson Hungria. Julgamento em 08/10/1953. In DJ de 20/05/1954, p. 5556. Disponível on line em http://redir.stf.jus.br/paginadorpub/paginador.jsp?docTP=AC\&docID=125324. Acesso em 24/7/2016. Ementa: São penhoráveis as cotas de sociedade limitada, substituindo-se afinal o credor-exequente nas vantagens e ônus do quotista executado, independentemente de assentimento dos demais. [...]. A decisão não encontrou acolhida em decisões posteriores da Suprema Corte durante a vigência do CPC de 1939.
}

Revista Brasileira de Direito Empresarial -le-SSN: 2526-0235| Curitiba | v. 2 | n. 2 | p. 198-221 | Jul/Dez. 2016. 
A decisão da Primeira Turma é criticável à luz do direito vigente à época, porque:

a) o fato de a lei do anonimato autorizar a transferência das ações nominativas não pode ser aplicado às quotas, haja vista a ausência de obrigatoriedade da escrituração de livro para registro de propriedade e/ou transferência no Decreto n. 3.708/19. Reitera-se que a lei de sociedades por ações não é supletiva ao Decreto e sim ao contrato. Ainda que o fosse, não se operaria a transferência das quotas na ausência do livro próprio; portanto, nas sociedades limitadas em que não houvesse tal livro a cessão não seria admitida, por contrariar a lei;

b) o ministro relator não enfrenta o fato de a quota ser parte do capital social e esse ser integrante do patrimônio da sociedade. Ademais, o art. 942, XII, do CPC vigente à época considerava absolutamente impenhoráveis os fundos sociais por dívidas particulares do sócio;

c) o argumento de que a penhora da quota não se confunde com a penhora dos fundos líquidos, embora correto, não pode conduzir ao ingresso compulsório do credor exequente na titularidade dos direitos de sócio se se reconhece a presença de affectio societatis na sociedade limitada. Se a lei das sociedades anônimas fosse aplicável supletivamente à sociedade por quotas para permitir a livre negociação das quotas, a propriedade só se transmitiria com a averbação do documento no livro de registro de quotas nominativas, exigência da lei do anonimato; e

d) a tese de que a quota não integra o patrimônio da sociedade e, portanto, o sócio pode dela dispor livremente ofende a autonomia patrimonial da sociedade;

A promulgação do novo Código de Processo Civil, em 1973, não alterou substancialmente a posição do STF quanto a penhora de quotas, em que pese o RE 90910/PR ter admitido a penhora de quotas à luz da novel legislação. Antes de analisa-la cabe tecer alguns comentários sobre a orientação do diploma em relação à penhora de direitos a partir do quadro comparativo abaixo.

\begin{tabular}{|l|l|}
\hline \multicolumn{1}{|c|}{ Código de Processo Civil de 1939 } & \multicolumn{1}{c|}{ Código de Processo Civil de 1973 } \\
\hline $\begin{array}{l}\text { Art. 930. A penhora poderá recair em quaisquer bens do } \\
\text { executado, na seguinte ordem: [...] }\end{array}$ & $\begin{array}{l}\text { Art. 655. Incumbe ao devedor, ao fazer a nomeação de } \\
\text { bens, observar a seguinte ordem: [...] } \\
\text { X-direitos e ações }\end{array}$ \\
$\begin{array}{l}\text { Art. 931. Consideram-se direitos e ações, para os efeitos } \\
\text { de penhora: as dividas ativas, vencidas, ou vincendas, } \\
\text { constantes de documentos; as ações reais, } \\
\text { reipersecutórias, ou pessoais para cobrança de dívida; as } \\
\text { quotas de herança em autos de inventário e partilha e os } \\
\text { fundos líquidos que possua o executado em sociedade } \\
\text { comercial ou civil. }\end{array}$ & Omisso \\
\hline $\begin{array}{l}\text { Art. 942. Não poderão absolutamente ser penhorados: } \\
\text { [...] }\end{array}$ & Art. 649. São absolutamente impenhoráveis: [...] \\
$\begin{array}{l}\text { XII- os fundos sociais, pelas dívidas particulares do } \\
\text { sócio, não compreendendo a isenção os lucros líquidos }\end{array}$ & \\
\hline
\end{tabular}

Revista Brasileira de Direito Empresarial -le-SSN: 2526-0235| Curitiba | v. 2 | n. 2 | p. 198-221 | Jul/Dez. 2016. 
verificados em balanço

Omisso

Percebe-se que o CPC73 não manteve a disposição do art. 931 do diploma anterior, na qual havia uma relação restritiva de direitos e ações suscetíveis de penhora. Nessa relação não se encontravam as quotas, pois elas não eram consideradas fundos líquidos. Ademais, os fundos sociais não permaneceram no rol de bens absolutamente impenhoráveis, já que nenhum inciso do art. 649 os incluiu. Sem embargo, não existia dispositivo que considerasse as quotas suscetíveis de penhora, tanto de sociedades comerciais quanto civis. Por outro lado, permanecia a divergência se a quota era de titularidade da sociedade, por integrar o fundo social, ou seria reputada bem com individualidade própria e existência distinta dentro do patrimônio social, como defendia João Eunápio Borges.

A consideração da quota como parte não integrante do fundo social, bem sobre o qual o sócio teria disponibilidade, permitiria, a princípio, sua penhora sob a égide do CPC73 pelas seguintes razões: (i) sendo bem do devedor-sócio, seria possível que ela respondesse pela satisfação do credor exequente, pois o art. 592, II, do CPC incluía os bens do sócio como sujeitos à execução, repetindo a norma do art. 888, II, do CPC anterior; (ii) a previsão quanto a impenhorabilidade dos fundos sociais não foi mantida; e (iii) não havia mais uma relação restritiva dos direitos suscetíveis de penhora, assim os direitos patrimoniais sobre a quota poderiam ser penhorados. A despeito destas ponderações, estaria de todo afastada a incidência do art. 292 do Código Comercial, haja vista que o art. 592, II, ao admitir que os bens do sócio fossem penhorados remetia à legislação societária a fixação das condições em que tal penhora seria possível ("nos termos da lei”)?

Mesmo que se adotasse o marco teórico da negociabilidade da quota pelo sócio, não se poderia olvidar a preferência que o Código Comercial estabelecia em favor dos credores sociais em detrimento dos particulares. Por conseguinte, em que pese a eliminação das disposições restritivas do CPC39, ainda seria necessário a prévia liquidação do patrimônio da sociedade para apuração dos fundos líquidos sobre os quais a penhora poderia recair, já que a lei processual não fixava tais condições? Estas e outras indagações aguardavam o posicionamento do STF para interpretar as disposições do CPC de 1973, decidindo ou não pela possibilidade de penhora de quotas de sociedade quando o contrato fosse omisso ou não a autorizasse ${ }^{16}$.

\footnotetext{
${ }^{16}$ Em 1978, a Primeira Turma do STF, no julgamento do Recurso Extraordinário n. 89228/RS, não conheceu do recurso, nos termos do voto do relator, por entender não violada a legislação federal nem ficar demonstrado dissídio
} 
De fundamental importância é o acórdão proferido no Recurso Extraordinário n. 90910/PR, julgado em 1980. Os ministros, por maioria, afirmaram ser penhorável a quota de sociedade por quotas de responsabilidade limitada por dívida do sócio ${ }^{17}$.

As decisões nas instâncias inferiores declararam a impenhorabilidade das quotas por integrarem o fundo social. O acórdão do STF contempla importantes considerações sobre as alterações promovidas pelo CPC73. Sustentou o recorrente que, se o legislador alterou as regras da impenhorabilidade, a penhora passou a ser admitida. A tese baseia-se no fato de o CPC autorizar o usufruto do quinhão do sócio em seu artigo 720 , portanto sua realização somente poderia ser efetivada se a quota fosse penhorada, pois ela é o "quinhão do sócio na empresa".

O ministro relator Xavier de Albuquerque, embora reconheça que o capital inclui as quotas, sendo o primeiro passivo da sociedade, não afasta o direito do sócio sobre o patrimônio líquido, direito esse consubstanciado na quota, bem de valor econômico e, como tal, deve responder pelas obrigações de seu titular. Não pode ser considerada verdade absoluta o argumento que o capital pertence à sociedade por integrar o seu patrimônio. Trata-se de "meia verdade" porque

É ele [o capital] pertencente à sociedade, sem dúvida, mas, não sendo fruto de geração espontânea, forma-se necessariamente pelas contribuições dos sócios que o integralizam. Por essas considerações, traduzidas pelas cotas, a sociedade deve aos sócios, que junto a ela possuem créditos correspondentes. Esses créditos são direitos que compõem os patrimônios individuais dos sócios, integrando-se na garantia geral com que contam seus respectivos credores ${ }^{18}$.

Nota-se que a posição albergada pelo relator quando à natureza da quota colide com a doutrina clássica ${ }^{19}$, que considera o fundo social como o acervo de bens ou valores componentes do

jurisprudencial, tal qual ocorreu no Recurso Extraordinário n. 75680/GO. Manteve-se, portanto, a posição majoritária antes do advento do CPC de 1973. O relator ministro Xavier de Albuquerque informa que o objetivo do recurso é modificar a decisão das instâncias inferiores que reconheceram a impenhorabilidade das quotas de sociedade por quotas de responsabilidade limitada ${ }^{16}$, mas não vê contrariedade nas decisões. BRASIL. Supremo Tribunal Federal. Primeira Turma. Recurso Extraordinário 89228/RS. Relator Min. Xavier de Albuquerque. Julgamento em 18/04/1978. In DJ de 12/05/1978, p. 3218.

${ }^{17}$ BRASIL. Supremo Tribunal Federal. Primeira Turma. Recurso Extraordinário 90910/PR. Relator Min. Xavier de Albuquerque. Julgamento em 21/10/1980. In DJ de 14/11/1980, p. 9492. Disponível on line em http://redir.stf.jus.br/paginadorpub/paginador.jsp?docTP=AC\&docID=184550

Acesso em 27/7/2016. Ementa: Sociedade de responsabilidade limitada. Dívida particular do sócio; penhorabilidade das respectivas cotas de capital. Recurso extraordinário conhecido e provido.

${ }_{18}$ Trecho do voto no ministro Xavier de Albuquerque proferido no acórdão do Recurso Extraordinário n. 90910/PR. Disponível on line em http://redir.stf.jus.br/paginadorpub/paginador.jsp?docTP=AC\&docID=184550. Acesso em 27/07/2016.

${ }^{19}$ As considerações do ministro Xavier de Albuquerque não sensibilizaram o ministro Cunha Peixoto, vencido no julgamento. O jurista manteve-se fiel à tese por ele esposada de que os bens com os quais os sócios entram para a formação do capital da sociedade perdem sua individualidade ao serem incorporados ao patrimônio da sociedade. A dedução lógica seria a injuridicidade da penhora recair sobre a parte ideal desse patrimônio por dívida que é do sócio e não da sociedade (terceira). Nessa linha de raciocínio, com a penhora o credor particular estaria assumindo uma posição privilegiada diante dos credores sociais, uma vez que a quota ficaria vinculada à satisfação do pagamento ao credor do 
patrimônio da sociedade, que a ela pertence (pessoa jurídica) e não aos sócios. Assim, o cerne da questão é determinar se o sócio ao ingressar na sociedade e receber quotas representativas do capital tem sobre elas propriedade e disponibilidade ou se, ao contrário, tem apenas um direito de crédito eventual, além dos fundos líquidos em caso de liquidação da sociedade. A discussão volta-se, então, para o art. 292 do Código Comercial e sua incidência antes e após a vigência do CPC de 1973.

Sobre o assunto o ministro Xavier de Albuquerque também se manifestou:

Penso, em suma, que, mesmo no regime do antigo Código de Processo Civil, podiam ser penhoradas, à falta de outros bens, as cotas de capital nas sociedades limitadas [referindose às cotas como fundos líquidos do sócio de sociedade comercial]. Era, a meu sentir, o sentido do art. 943, II, daquele estatuto, que não excepcionava o disposto no art. 942, XII, porque regulara tema diverso 20 .

Prosseguindo em seu voto, o relator discorda da intepretação do art. 292 do C. Comercial:

[...] o dispositivo não sugere distinção entre fundos líquidos e contribuição ou cota de capital, como se estas não se incluíssem naqueles. Fundos líquidos, a meu ver, significam aí a participação proporcional do sócio no patrimônio líquido da sociedade, participação que pode ser maior ou menor do que a expressão monetária nominal da contribuição do sócio na formação do capital social, do mesmo modo que pode igualá-la, tudo dependendo de ser o ativo menor do que o passivo, ou maior do que este, ou igual a este. A expressão quota líquida -, que o mesmo dispositivo emprega em seu segundo parágrafo, parece-me que corrobora esta opinião $[\ldots]^{21}$.

A possibilidade de ser rompida a affectio societatis caso a quota viesse a ser penhorada não sensibilizou o ministro Xavier de Albuquerque. Caso tal argumento fosse acatado, uma vedação contratual ao ingresso de terceiro na sociedade (convenção privada) seria capaz de afastar a penhora e o princípio de que o patrimônio do devedor responde pelas suas obrigações. Tal ponderação apresentada é de suma importância e representa um posicionamento avançado à época: a impenhorabilidade da quota decorrente do contrato (vedação da cessão a terceiros sem o placet dos sócios) não poderia ser oposta ao credor particular de sócio em prol da preservação da affectio societatis, porque a lei vigente não mais consagrava a impenhorabilidade dos fundos sociais.

sócio sem a apuração prévia dos débitos da sociedade e liquidação do seu patrimônio. O ministro demonstrou sua preocupação com o ingresso forçado na sociedade do arrematante da quota, eis que a penhora leva à sua alienação em hasta pública. Para ele "a sociedade comercial constitui um contrato em que os sócios representam parte essencial", sendo inegável a natureza intuitu personae do contrato. Com a impenhorabilidade o legislador pretendeu evitar que terceiros participem da sociedade contra a vontade dos sócios (promovendo a discórdia no seio da sociedade), que não seriam obrigados a aceita-lo em razão doe elementos pessoais do sócio que tiver sua quota penhorada. Entretanto advertiu: "Mas, se os próprios membros da sociedade abrem mão desta garanta, possibilitando a transferência da cota a estranhos, já não há razão jurídica ou moral para impedir a venda judicial da parte do sócio devedor". Disponível on line em http://redir.stf.jus.br/paginadorpub/paginador.jsp?docTP=AC\&docID=184550. Acesso em 27/07/2016.

${ }^{20}$ Ibidem.

${ }^{21}$ Ibidem.

Revista Brasileira de Direito Empresarial -le-SSN: 2526-0235| Curitiba | v. 2 | n. 2 | p. 198-221 | Jul/Dez. 2016. 
Percebe-se que o CPC73 produziu uma mudança relativa e parcial na análise da penhorabilidade de quotas no STF diante da eliminação de restrições contidas no CPC anterior ${ }^{22}$. Não se pode concluir, entretanto, pela superação da tese da impenhorabilidade quando o contrato dispusesse sobre a restrição na cessão, ou mesmo que na ausência de permissivo contratual fosse consentida a penhora de quota pelo credor do sócio.

A partir de 1989, precisamente no dia 7 de abril, instalou-se o Superior Tribunal de Justiça, que passou a ter competência para julgar, em recurso especial, as causas decididas, em única ou última instância, pelos Tribunais Regionais Federais ou pelos tribunais dos Estados, do Distrito Federal e Territórios, quando a decisão recorrida contrariar tratado ou lei federal, ou negar-lhes vigência, ou quando der a lei federal interpretação divergente da que lhe haja atribuído outro tribunal.

\section{A EVOLUÇÃO DA JURISPRUDÊNCIA SOBRE A PENHORA DE QUOTA NO ÂMBITO DO SUPERIOR TRIBUNAL DE JUSTIÇA}

A pesquisa da jurisprudência do STJ teve por marco temporal os anos de 1992 a 1996 porque não se verificou nenhum julgado sobre penhora de quota antes do primeiro ano e, a partir de 1996, as decisões convergiram para a penhora irrestrita. Entretanto, os dois acórdãos mais importantes estão compreendidos entre os anos de 1992 a 1994, pois foi nesse período que a Terceira e Quarta Turmas se debruçaram sobre três questões nucleares: a penhora da quota pode ser admitida e efetivada quando o contrato contiver cláusula proibitiva de cessão de quotas ou quando essa depender do consentimento dos sócios? Haveria, nesses casos, impenhorabilidade da quota por ato de vontade em face da previsão de inalienabilidade do art. 649, I, do CPC? Em se admitindo a

\footnotetext{
${ }^{22}$ Embora não tenha tratado da penhora de quota, digno de nota é o posicionamento, por maioria, adotado pela Segunda Turma, em 1984, no julgamento do Recurso Extraordinário 85271/MG, acolhendo os argumentos tecidos pelo ministro Moreira Alves, contrários aos do ministro Leitão de Abreu sobre a natureza da quota e a impossibilidade de ser objeto de posse: "Ora, a quota é mera participação do sócio no capital social, não podendo, em nosso direito, consubstanciarse, sequer, em cártula, para que se possa pretender que sobre esta haveria propriedade. Por outro lado, ela propicia a seu titular posição jurídica de sócio, mas não a de proprietário ou de possuidor sobre os bens sociais, cuja propriedade e posse são da sociedade, pessoa jurídica distinta das pessoas físicas dos sócios" (disponível on line em http://redir.stf.jus.br/paginadorpub/paginador.jsp?docTP=AC\&docID=179426. Acesso em 31/07/2016.

Também no ano de 1984, a mesma Segunda Turma ao apreciar o Recurso Extraordinário n. 95381/PR não conheceu do recurso, por entender que a decisão do Tribunal de Justiça do Estado do Paraná sobre a impenhorabilidade das quotas de sociedade "limitada" não ofendia a legislação federal. Em seu voto o relator ministro Décio Miranda considerou correta a decisão de segunda instância, fundamentada no art. 292 do Código Comercial, porque somente seriam penhoráveis os fundos líquidos que o sócio possui na sociedade. Ainda que a sociedade seja do tipo limitada, se lhe aplica o artigo 292 diante da omissão no Decreto n. 3.708/19, por ser vedação de caráter abrangente.
} 
penhora, como ficariam sociedades constituídas intuitu personae e os sócios diante da possibilidade de ingresso de um estranho?

Em 15 de dezembro de 1992 a Terceira Turma proferiu duas decisões sobre penhora de quotas. A primeira no julgamento do REsp 16540/PR ${ }^{23}$, e outra no julgamento do REsp 21223/PR ${ }^{24}$. Pela sua importância a análise recairá sobre a segunda decisão.

No julgamento do REsp 21223/PR a Turma seguiu o voto do ministro relator Dias Trindade que privilegiou a legislação processual civil (art. 649) e o Decreto n. 3.708/19. Para o relator se as quotas não constam da relação de bens absolutamente impenhoráveis não se poderia aplicar o art. 292 do Código Comercial em razão do tipo societário ser regulado por lei própria, que silenciava sobre a matéria. O voto omite qual deve ser a disposição de direito material aplicável diante da lacuna do Decreto n. 3708/19, amparando-se tão somente no art. 591 do CPC para considerar a quota bem integrante do patrimônio do devedor e, como tal, sujeito ao cumprimento das obrigações contraída por ele perante seus credores. Em relação ao caráter pessoal da sociedade, o exercício do direito de preferência dos sócios na arrematação da quota asseguraria a manutenção do quadro social.

Em 1994, o ministro Sálvio de Figueiredo Teixeira, relator do REsp 30854/SP, trouxe importante contribuição em seu voto para a evolução da interpretação sobre a penhora irrestrita da quota $^{25}$. A decisão serviu de precedente para decisões futuras tanto na Terceira quanto na Quarta Turma ${ }^{26}$, pacificando em pouco tempo a posição da Corte.

\footnotetext{
${ }^{23}$ BRASIL. Superior Tribunal de Justiça. Terceira Turma. Recurso Especial 16540/PR. Relator Min. Waldemar Zveiter. Julgamento em 15/12/1992. In DJ de 08/03/1993, p.3113. Ementa: PROCESSUAL - PENHORABILIDADE DE QUOTAS SOCIAIS - MATERIA DE FATO.

I - Doutrina e jurisprudência dominante são acordes em que a penhora de quotas sociais não atenta, necessariamente, contra o princípio da affectio societatis ou contra o da intuitu personae da empresa, eis que a sociedade de responsabilidade limitada dispõe de mecanismo de autodefesa.

II - Matéria de prova ou de interpretação de contrato não se reexaminam em especial (sumulas 05 e 07 do STJ).

III - Recurso não conhecido.

${ }^{24}$ BRASIL Superior Tribunal de Justiça. Terceira Tuma. Recurso Especial 21223/PR. Relator Min. Dias Trindade. Julgamento em 15/12/1992. In DJ de 01/03/1993, p. 2510. Ementa: PROCESSUAL CIVIL. PENHORA DE QUOTAS EM SOCIEDADE DE RESPONSABILIDADE LIMITADA. Responde o devedor com todos os seus bens, presentes ou futuros, para o cumprimento de suas obrigações, não havendo lei que exclua da execução as quotas do sócio em sociedade de responsabilidade limitada.

${ }^{25}$ BRASIL Superior Tribunal de Justiça. Quarta Turma. Recurso Especial 30854/SP. Relator Min. Sálvio de Figueiredo Teixeira. Julgamento em 08/03/1994. In DJ de 18/04/1994, p. 8500. Ementa: PROCESSO CIVIL E DIREITO COMERCIAL. LEGITIMIDADE ATIVA DA SOCIEDADE PARA OPOR EMBARGOS DE TERCEIRO CONTRA PENHORA DE COTAS DO SOCIO POR DIVIDA PARTICULAR DESTE. PENHORABILIDADE DAS COTAS DE SOCIEDADE DE RESPONSABILIDADE LIMITADA. DOUTRINA. PRECEDENTES. RECURSO PROVIDO.

I- Representando as cotas os direitos do cotista sobre o patrimônio líquido da sociedade, a penhora que recai sobre elas pode ser atacada pela sociedade via dos embargos de terceiro.

II- A penhorabilidade das cotas não vedada em lei, é de ser reconhecida.
} 
Um dos obstáculos tradicionalmente levantados era a possibilidade de ingresso forçado do terceiro na sociedade se a quota fosse arrematada quando o contrato social vedasse sua cessão. Este era um argumento crucial levantado pelo ministro Cunha Peixoto e que por muito tempo prevaleceu.

O ministro Sálvio propôs a confrontação e interação das normas processuais, de interesse público, com as normas de direito comercial, de interesse privado, apresentando os seguintes argumentos para a penhora irrestrita de quotas:

a) a impenhorabilidade só pode ser fixada ou autorizada por lei e não por convenção privada (contrato), em respeito ao direito de terceiros. Não se pode considerar a quota bem absolutamente impenhorável quando o contrato proibir sua cessão, sendo inaplicável o art. 649, I, do CPC para motivar vedação à penhora. Se o sócio aceita a cláusula contratual que restringe a negociação da quota, ou a pró́be, tal limitação voluntária ao direito de propriedade não pode afastar a quota do cumprimento de suas obrigações;

b) com suporte na doutrina de Carlos Henrique Abrão ${ }^{27}$, o ministro ponderou que não se pode deixar de considerar a quota como direito, bem incorpóreo dotado de conteúdo econômico, e, portanto, suscetível de penhora nos ternos do inciso X do art. 655 do CPC;

c) a penhora deve ocorrer mesmo que o contrato proíba sua cessão, porém o credor não adquirirá necessariamente o status de sócio porque a sociedade tem mecanismos para evitar esta situação; e

d) ainda apoiado em Carlos Henrique Abrão, o julgador invocou o artigo 651 do CPC, interpretando-o extensivamente para considerar a sociedade - ainda que não seja devedora legitimada na condição de terceiro interessado para remir a execução e evitar o ingresso de estranho em seu seio. A sociedade também poderia efetuar a liquidação da quota e, se necessário, reduzir o

III- Os efeitos da penhora incidente sobre as cotas sociais hão de ser determinados em atenção aos princípios societários, considerando-se haver, ou não, no contrato social proibição a livre alienação das mesmas.

IV- Havendo restrição contratual, deve ser facultado a sociedade, na qualidade de terceira interessada, remir a execução, remir o bem ou conceder-se a ela e aos demais sócios a preferência na aquisição das cotas, a tanto por tanto (CPC, arts. $1117,1118$ e 1119$)$.

V - Não havendo limitação no ato constitutivo, nada impede que a cota seja arrematada com inclusão de todos os direitos a ele concernentes, inclusive o "status" de sócio.

${ }^{26}$ A guisa de ilustração citem-se os REsp 201181 (Sexta Turma, relator Min. Fernando Gonçalves, julg. 29/03/2000), REsp 236939 (Quarta Turma, relator Min. Aldir Passarinho Junior, julg. 15/06/2000), REsp 234391 (Terceira Turma, relator Min. Carlos Alberto Direito, julg. 14/11/2000), e REsp 221625 (Terceira Turma, relatora Min. Nancy Andrighi, julg. 07/12/2000) e o Agravo Regimental no Agravo de Instrumento 347829 (Terceira Turma, relator Min. Ari Pargendler, julg. 27/08/2001).

${ }^{27}$ Cf. ABRÃO, Carlos Henrique. Penhora de Cotas de Sociedade de Responsabilidade Limitada. 2.ed. São Paulo: Revista dos Tribunais, 1991 apud TEIXEIRA, Sálvio de Figueiredo. Recurso Especial n. 30854/SP [Superior Tribunal de Justiça], $1994 . \quad$ Disponível on em https://ww2.stj.jus.br/processo/ita/documento/mediado/?num_registro=199200334148\&dt_publicacao=18-041994\&cod_tipo_documento=3 
capital. Alternativamente a sociedade poderia remir o bem ou exercer, juntamente com os sócios, o direito de preferência à aquisição das quotas, respectivamente, com base nos arts. 787 e 1.117 a 1.119 do $\mathrm{CPC}^{28}$.

O ministro Sálvio deixa claro que, em qualquer hipótese, a quota pode ser penhorada, mas a solução será diversa dependendo da presença ou não de cláusula restritiva no contrato. Caso esse contenha tal cláusula, seriam aplicáveis as soluções de remição da execução, liquidação da quota em favor do credor, remição do bem ou direito de preferência. Ao contrário, diante da omissão no contrato ou previsão de livre cessão da quota não haveria nenhum inconveniente em se decretar a penhora e o arrematante passaria a exercer todos os direitos de sócio $^{29}$.

Percebe-se que a grande contribuição do STJ para a evolução da intepretação e aplicação do instituto da penhora sobre a quota está centrada em dois aspectos: a) admissibilidade da penhora irrestrita, mesmo que a cessão seja proibida pelo contrato, afirmando a prevalência da disposição do art. 591 do CPC sobre qualquer convenção privada; b) concepção de alternativas para evitar a arrematação ou adjudicação da quota por estranho ao quadro societário, que abalariam o caráter intuitu personae da sociedade e o princípio da affectio societatis.

\footnotetext{
${ }^{28}$ Não se pode deixar de apreciar os argumentos, alguns deles "forçados" e com grande "elasticidade" na aplicação da norma jurídica, utilizados para motivar a penhora das quotas, contra o teor do contrato. Ainda que se considerasse a sociedade como parte interessada no pagamento, a teor do artigo 930 do Código Civil de 1916 (e ao correspondente art. 304 do Código de 2002), justificando o alargamento do termo "devedor" no art. 651 do CPC, não é correto "colocar palavras na boca do legislador" ou considerar o instituto do condomínio em bem indivisível sinônimo de propriedade de quota de sociedade.

Eis o teor do art. 787 do CPC: "É lícito ao cônjuge, ao descendente, ou ao ascendente do devedor remir todos ou quaisquer bens penhorados, ou arrecadados no processo de insolvência, depositando o preço por que foram alienados ou adjudicados". Percebe-se que a sociedade não tem vínculo matrimonial ou de parentesco com o devedor, talvez algum dos sócios tenha, mas jamais a sociedade. Como poderia ela invocar o dispositivo para remir a quota penhorada? Portanto, com a devida vênia, tal solução não tinha amparo legal conforme a legislação processual civil vigente, sendo pura construção doutrinária.

O voto também faz menção aos arts, 1.117 a 1.119 do CPC, inseridos no Título II (Dos Procedimentos Especiais de Jurisdição Voluntária), Capítulo II (Das Alienações Judiciais). Nota-se que toda a questão ventilada diz respeito ao processo de execução e à penhora, que não é um procedimento de jurisdição voluntária. Ademais, seria a quota coisa comum indivisível, objeto de copropriedade entre os sócios? Há alguma relação ou identidade entre a quota e um bem em condomínio para ser aplicado o art. 1.118, I, do CPC, que garante na alienação judicial voluntária de coisa comum direito de preferência, tanto por tanto, do condômino ao estranho? Evidentemente que não. Por conseguinte, não se considera pertinente afirmar - até a respectiva positivação do direito de preferência, ocorrida com a alteração da legislação processual em 2006 - que a sociedade e os sócios poderiam exercer direito de preferência tanto por tanto com base no art.1.118, I, do CPC. Fica aqui a perplexidade com tal ilação, reproduzida em várias decisões posteriores do STJ sem a menor análise comparativa dos dispositivos invocados com a relação societária, que não é, data maxima venia, condominial.

${ }^{29}$ Entre 1992 a 1995 poucas decisões reconheceram a impenhorabilidade da quota quando o contrato tivesse cláusula restritiva ou impeditiva de sua cessão a terceiros (cf. REsp 16540/PR; REsp 34882/RS; REsp 37254/SP; REsp 30854/SP; REsp n. 19018/PR). A partir de 1996 a jurisprudência uniformizou-se nas Turmas da Segunda Seção pela penhorabilidade irrestrita, sendo a última decisão em contrário proferida em 2000 no REsp 148947/MG.
} 


\section{AS CONTRIBUIÇÕES DO CÓDIGO CIVIL DE 2002, DA LEI N. 11.382/2006 E DO CPC DE 2015}

Embora a jurisprudência no STJ já estivesse pacificada antes da entrada em vigor do Código Civil, verifica-se avanço desse diploma no tratamento da penhora da quota por dívida do sócio pelas seguintes razões: a) ao revogar em seu art. 2.045 a Parte Primeira do Código Comercial, sepultou-se a possibilidade de o art. 292 fundamentar o impedimento à penhora das quotas na sociedade limitada, por aplicação supletiva ao Decreto n. 3.708/19, também revogado, como em outros tipos societários. Recorde-se que o art. 292 somente admitia que o credor particular do sócio excutisse os fundos líquidos que ele possuísse na sociedade. Assim, na constância da sociedade somente poderiam ser penhorados os lucros não distribuídos apurados em balanço ou créditos em favor do sócio reconhecidamente devidos; b) o Código alterou o entendimento acerca da posição do credor de sócio vis-à-vis dos credores sociais, introduzindo nas disposições da sociedade simples (art. 1.026) regras para regular o pagamento; c) passou a ser admitida, por ilação, a penhora da quota sem que sociedade tenha seu patrimônio liquidado em dissolução. Ademais, cuidou o legislador de resguardar o caráter personalista do contrato de sociedade ao prever que o pagamento ao credor não se dará mediante alienação judicial da quota - hipótese em que ela poderia ser arrematada por terceiro estranho à sociedade - e sim após prévia apuração dos haveres do sócio, intimada a sociedade para tal; e d) como não há alienação judicial da quota, as soluções alvitradas no REsp 30854/SP (remição da execução, remição do bem ou direito de preferência aos sócios) não seriam mais aplicadas, já que são mecanismos de defesa da sociedade ao ingresso de estranho adotados em caso de alienação judicial.

Verifica-se que o caput do art. 1.026 não inovou no ordenamento ao dispor que "O credor particular de sócio pode, na insuficiência de outros bens do devedor, fazer recair a execução sobre o que a este couber nos lucros da sociedade, ou na parte que lhe tocar em liquidação". Muito antes o Código Comercial (art. 292), o Decreto n. 737 (art. 498) e o Código de Processo Civil de 1939 (art. 943, II) já dispunham que poderiam ser executados (penhorados), na falta de outros bens “desembargados”, os fundos líquidos que o devedor possuísse na sociedade comercial.

O Código Civil estabeleceu uma prioridade para a penhora dos lucros ou da quota partilhada em caso de liquidação, prevendo que a execução só poderia recair sobre os primeiros ou sobre a segunda "na insuficiência de outros bens do devedor", numa clara alusão ao art. 943, II, do CPC39, porém exemplificando tais "fundos líquidos" ao invés de usar essa expressão. Atente-se

Revista Brasileira de Direito Empresarial -le-SSN: 2526-0235| Curitiba | v. 2 | n. 2 | p. 198-221 | Jul/Dez. 2016. 
também ao fato de o inciso XII do art. 942 do CPC39 admitir a penhora dos lucros líquidos verificados em balanço por dívidas particulares do sócio.

A inovação advém no parágrafo único do art. 1.026, cuja incidência se dá se a sociedade não estiver dissolvida. Fica o credor autorizado a requerer a liquidação da quota do devedor, cujo valor, apurado a princípio mediante levantamento de balanço especial, será depositado em dinheiro pela sociedade, no juízo da execução, até noventa dias após aquela liquidação. Sabe-se que o art. 292 do Código Comercial não permitia que o credor de sócio excutisse a quota do patrimônio social para a solução de seu crédito. Ao invés de admitir a liquidação da quota, o Código exigia que primeiro se liquidasse a sociedade ou, alternativamente, se provasse que o devedor tinha saldos à sua disposição ainda não pagos. Tais exigências tornam-se superadas com o advento do Código Civil de 2002 porque se nota estar implicitamente autorizada a penhora (i) de direitos patrimoniais decorrentes da titularidade da quota do sócio, na insuficiência de outros bens, e (ii) da própria quota se a sociedade não estiver dissolvida, ou seja, se não tiver ocorrido ainda a partilha do seu acervo patrimonial $^{30}$.

Pode-se concluir que o Código Civil "sepultou" a tese da impenhorabilidade relativa da quota sob o pálio da proteção ao caráter personalista da sociedade e ao princípio da affectio societatis. É indubitável que o tipo simples, no qual se insere o art. 1.026, é adotado pelos sócios que desejam constituir uma sociedade intuitu personae; todavia, a despeito de ser uma sociedade de pessoas, o legislador não impediu a penhora da quota e, em seguida, a apuração de seu valor pela sociedade.

Não obstante, atentou o legislador para a possibilidade de ingresso compulsório de terceiro estranho ao quadro social, por via de arrematação da quota ou sua adjudicação por credor não sócio, e os problemas internos a comprometer a continuidade da sociedade, quiçá conduzindo à sua dissolução em situações extremas. Para preservar o caráter intuitu personae o exequente fica impedido do ingressar na sociedade e a quota não será levada à hasta pública, cabendo à sociedade realizar o pagamento ao credor através da liquidação da quota.

No final de 2006 foi promulgada, com vetos, a Lei n. 11.382. O art. $2^{\circ}$ alterou a redação do art. 655 do CPC para incluir, de modo inédito, no inciso VI as ações e quotas de sociedades

\footnotetext{
${ }^{30}$ Cabe sublinhar que o Código Civil não emprega o termo "dissolução" em sentido amplo - total ou parcial - já que ao se referir aos casos em que caberia a "dissolução parcial" adota corretamente a expressão "resolução da sociedade em relação a um sócio". Destarte, a incidência do parágrafo único ("se a sociedade não estiver dissolvida") deve ser interpretada a partir do termo dissolução em seu sentido estrito (apenas "total"), quando ocorrerá a liquidação da quota do sócio e não do patrimônio da sociedade.
} 
empresárias como bens objeto de penhora. $\mathrm{O}$ art. $3^{\circ}$ acrescentou o art. 685-A, tratando da Adjudicação e, no $\S 4^{\circ}$, passou a ser previsto o direito de preferência aos sócios em caso de penhora de quotas procedida por exequente alheio à sociedade, sendo essa previamente intimada.

Percebe-se a omissão das quotas de sociedades simples ${ }^{31}$ no inciso VI do art. 655. Teriam elas sido consideradas bens absolutamente impenhoráveis? Absolutamente não! São penhoráveis as quotas de sociedades do tipo simples e de sociedade simples que adote tipo de sociedade empresária, exceto as sociedades por ações, com base no art. 1.026 do Código Civil, não sendo necessário recorrer à legislação processual para admitir a penhorabilidade. Portanto, não se pode concluir que a omissão às quotas de sociedades simples no inciso VI do art. 655 do CPC autorizou implicitamente a impenhorabilidade. A ausência de previsão no art. 649 do CPC da quota de sociedade simples não permite tacitamente inclui-la no rol de bens impenhoráveis por lei, nem o contrato pode torna-la impenhorável ao proibir sua cessão a terceiros, diante do art. 592, II, do CPC.

Até a revogação do CPC73 a penhora de quotas de sociedades simples só se fundamentava expressamente no Código Civil, embora se pudesse extrair, por ilação, seu cabimento pela interpretação teleológica e sistemática dos arts. 591, 592, II e 649 do CPC. Não obstante, a lei civil dispõe expressamente que a quota será liquidada pela sociedade, não prevendo outra solução. Caberá à sociedade levantar o balanço de determinação, que podem chegar a esvaziar por completo o valor patrimonial da quota. Portanto, a liquidação da quota é incompatível com a adjudicação ao credor. Caso fosse aplicável o art. 685-A e seu $§ 4^{\circ}$, o credor adquiriria o status socii se os sócios não exercessem o direito de preferência. Entende-se que a mens lege não foi eliminar a affectio societatis e sim preservá-la sem, no entanto, afastar a quota da constrição judicial. Quisesse o legislador equiparar o tratamento das quotas de sociedades empresárias e simples em todos os aspectos não teria, propositalmente, omitido essas na nova redação do inciso VI do art. 655 .

O atual Código de Processo Civil (Lei n. 13.105/2015) trouxe como inovações: (i) a inclusão da penhora de quotas de sociedade simples no art. 835, IX; (b) o art. 861 dispõe sobre regras específicas para a penhora de quotas e ações de sociedades, exceto companhias abertas ${ }^{32}$.

\footnotetext{
${ }^{31}$ Por sociedade simples e empresária, para os fins de interpretação do art. 655 do CPC toma-se por base o art. 982 do Código Civil e o critério de identificação do objeto da sociedade, ressalvando-se a disposição do parágrafo único, segundo a qual as sociedades por ações são sempre empresárias e as sociedades cooperativas são sempre simples.

${ }^{32}$ Art. 861. Penhoradas as quotas ou as ações de sócio em sociedade simples ou empresária, o juiz assinará prazo razoável, não superior a 3 (três) meses, para que a sociedade:

I - apresente balanço especial, na forma da lei;

II - ofereça as quotas ou as ações aos demais sócios, observado o direito de preferência legal ou contratual;

III - não havendo interesse dos sócios na aquisição das ações, proceda à liquidação das quotas ou das ações, depositando em juízo o valor apurado, em dinheiro.
} 
Numa análise global pode-se afirmar que as mudanças introduzidas pelo CPC2015 tiveram como foco o reconhecimento implícito de affectio societatis nas sociedades simples e empresárias, salvo nas companhias abertas ${ }^{33}$. Da interpretação sistemática dos parágrafos do art. 861 verifica-se que o credor não pode adjudicar de imediato as ações de companhia fechada (independentemente de se verificar casuisticamente o caráter intuitu personae), de sociedade em comandita por ações ou sociedades de outros tipos. Foi estabelecida no caput e $\S 1^{\circ}$ do art. 861 uma ordem de preferência no pagamento que privilegia a transferência das quotas/ações do executado para outro(s) sócio(s), mantendo o quadro social inalterado. Contudo, se todas as alternativas forem empregadas sem êxito quanto ao pagamento do credor, as quotas ou ações serão alienadas judicialmente.

O legislador almejou compatibilizar o interesse da sociedade na manutenção de seu quadro e a utilização prévia de mecanismos de autodefesa com a necessidade de assegurar o pagamento ao credor. Se não houver êxito com a adoção das providências preventivas à liquidação ou essa for excessivamente onerosa à sociedade, de acordo com o art. 861, § $5^{\circ}$, a quota ou a ação seguirá o trâmite da alienação judicial com transmissão de todos os direitos a terceiro, inclusive o status socii.

\section{CONCLUSÃO}

A penhora de quotas é um dos temas mais instigantes do direito societário e sofreu mudanças legislativas promovidas para suprir lacunas e criar alternativas à preservação do quadro societário. De início o entendimento pacífico na doutrina e sobejamente invocado pela jurisprudência era pela impossibilidade de penhora da quota em si, pois essa pertencia à sociedade e não ao sócio. Fundava-se a assertiva na personalidade jurídica da sociedade a quem cabia a titularidade do patrimônio, sendo a quota um bem integrante dele; ao sócio somente eram

\footnotetext{
$\S 1^{0}$ Para evitar a liquidação das quotas ou das ações, a sociedade poderá adquiri-las sem redução do capital social e com utilização de reservas, para manutenção em tesouraria.

$\S 2^{\underline{0}} \mathrm{O}$ disposto no caput e no $\S 1^{\underline{0}}$ não se aplica à sociedade anônima de capital aberto, cujas ações serão adjudicadas ao exequente ou alienadas em bolsa de valores, conforme o caso.

$\S 3^{\underline{0}}$ Para os fins da liquidação de que trata o inciso III do caput, o juiz poderá, a requerimento do exequente ou da sociedade, nomear administrador, que deverá submeter à aprovação judicial a forma de liquidação.

$\S 4^{\circ} \mathrm{O}$ prazo previsto no caput poderá ser ampliado pelo juiz, se o pagamento das quotas ou das ações liquidadas:

I - superar o valor do saldo de lucros ou reservas, exceto a legal, e sem diminuição do capital social, ou por doação; II colocar em risco a estabilidade financeira da sociedade simples ou empresária.

$\S 5^{\circ}$ Caso não haja interesse dos demais sócios no exercício de direito de preferência, não ocorra a aquisição das quotas ou das ações pela sociedade e a liquidação do inciso III do caput seja excessivamente onerosa para a sociedade, o juiz poderá determinar o leilão judicial das quotas ou das ações.

${ }^{33}$ Diante da admissão dos valores mobiliários de companhias abertas à negociação em bolsa de valores ou mercado de balcão, não há empecilho para a adjudicação direta pelo credor ou alienação das ações, cf. art. 861 , § $2^{\circ}$.
} 
reservados os fundos líquidos, ou ainda em créditos decorrentes de negócios entabulados com a pessoa jurídica ou lucros apurados em balanço.

O Decreto n. 737/1850 e o CPC39 corroboraram a orientação do artigo 292 do Código Comercial, que interpretado em conjunto com o art. 334 do mesmo diploma, permite concluir que caberia aos sócios autorizar a penhora da quota ou vedá-la para a manutenção do quadro social.

Com o Decreto n. 3.708/19, a possibilidade de penhora da quota passou a ganhar espaço na doutrina e na jurisprudência, com destaque para o pronunciamento do STF em 1953 no RE 24.118/SP, onde a penhora foi admitida desde que não houvesse disposição em contrário no contrato.

O CPC73 não reproduziu a norma do art. 931 do diploma anterior que limitava a penhora aos fundos líquidos; sem embargo não havia nenhum dispositivo que considerasse as quotas objeto de penhora. Percebeu-se uma módica evolução da jurisprudência do STF no julgamento do RE 90910/PR, em 1980, contudo ainda limitada à análise do personalismo da sociedade e do princípio da affectio societatis, admitindo-se a impenhorabilidade da quota a depender da feição da sociedade.

Coube ao STJ fixar os delineamentos da penhora de quotas, alguns deles mantidos pelo CPC vigente. Passou a ser permitida a penhora irrestrita da quota, ou seja, mesmo que a cessão seja proibida no contrato ou condicionada à autorização prévia dos sócios, afirmando-se a prevalência da disposição do art. 591 do CPC sobre qualquer convenção privada. Ademais, para evitar que a quota fosse arrematada por estranho ao quadro societário, abalando o princípio da affectio societatis, foram propostas, com supedâneo na doutrina, alternativas não previstas na legislação da época, a partir de amplíssima analogia e interpretação extensiva de dispositivos da lei processual.

Com o Código Civil de 2002 passou a ser implicitamente admitida a penhora da quota. O legislador preocupou-se em resguardar o caráter personalista do contrato de sociedade ao prever que o pagamento ao credor não se dará mediante alienação judicial, mas após prévia apuração dos haveres do sócio. O caput do art. 1.026 estabeleceu uma prioridade para a penhora dos lucros ou da quota partilhada em caso de liquidação, prevendo que a execução só poderia recair sobre os primeiros ou sobre a segunda "na insuficiência de outros bens do devedor". O parágrafo único do art. 1.026, cuja incidência se dá se a sociedade não estiver dissolvida, autoriza ao credor requerer a liquidação da quota do devedor, cujo valor, apurado a princípio mediante levantamento de balanço especial, será depositado em dinheiro, no juízo da execução, até 90 dias após aquela liquidação. 
A Lei n. 11.382/2006 incluiu as ações e quotas de sociedades empresárias como bens suscetíveis de penhora, omitindo as quotas de sociedade simples, que só foi prevista no CPC atual. Passou a ser positivado o direito de preferência em favor dos sócios em caso de penhora de quotas procedida por exequente alheio à sociedade, sendo essa previamente intimada.

As inovações do CPC 2015 no tema tiveram por alvo o reconhecimento implícito de affectio societatis nas sociedades, salvo nas companhias abertas. A interpretação sistemática dos parágrafos do art. 861 permite concluir a impossibilidade de adjudicação imediata das ações ou quotas, porque foi criada uma ordem de preferência no pagamento. Tal ordem privilegia a transferência das quotas/ações do executado para outro(s) sócio(s). Contudo, se nem todas as alternativas puderem ser empregadas ou não tiverem sem êxito, as quotas ou ações serão alienadas judicialmente.

O legislador compatibilizou o interesse da sociedade e a utilização prévia de mecanismos de autodefesa com a necessidade de assegurar o pagamento ao credor. Infrutíferas as providências preventivas à liquidação ou essa for excessivamente onerosa à sociedade, a quota ou a ação seguirá o trâmite da alienação judicial com transmissão de todos os direitos a terceiro, inclusive o status socii.

\section{REFERÊNCIAS}

ABRÃO, Carlos Henrique. Penhora de Cotas de Sociedade de Responsabilidade Limitada. 2.ed. São Paulo: Revista dos Tribunais, 1991

BORGES, João Eunápio. Curso de Direito Comercial Terrestre. 3.ed. Rio de Janeiro: Forense, 1967.

BRASIL. Superior Tribunal de Justiça. Terceira Turma. Recurso Especial 16540/PR. Relator Min. Waldemar Zveiter. Julgamento em 15/12/1992. In DJ de 08/03/1993, p.3113.

. Recurso Especial 21223/PR. Relator Min. Dias Trindade. Julgamento em

15/12/1992. In DJ de 01/03/1993, p. 2510.

. Recurso Especial 30854/SP. Relator Min. Sálvio de Figueiredo Teixeira.

Julgamento em 08/03/1994. In DJ de 18/04/1994, p. 8500.

. Recurso Especial 34692/SP. Relator Min. Cesar Asfor Rocha. Julgamento em 10/09/1996. In DJ de 29/10/1996, p. 41650.

BRASIL. Supremo Tribunal Federal. Segunda Turma, Recurso Extraordinário 6.639/SP. Relator

Min. Orosimbo Nonato. Julgamento em 09/07/1947. Disponível on line em

http://redir.stf.jus.br/paginadorpub/paginador.jsp?doc TP=AC\&docID=506059

Acesso em 24/7/2016

Revista Brasileira de Direito Empresarial -le-SSN: 2526-0235| Curitiba | v. 2 | n. 2 | p. 198-221 | 
. Primeira Turma, Recurso Extraordinário 24.118/SP. Relator Min. Nelson Hungria. Julgamento em 08/10/1953. In DJ de 20/05/1954, p. 5556.

Recurso Extraordinário 34.680/RS. Relator Min. Nelson Hungria.

Julgamento em 27/01/1958. In DJ de 29/05/1958.

. Recurso Extraordinário 47275/BA. Relator para o acórdão Min. Pedro

Chaves. Julgamento em 06/12/1962. In DJ de 05/06/1963.

Tribunal Pleno. Embargos no Recurso Extraordinário 47275. Relator Min.

Antônio Villas Boas. Julgamento em 09/03/1964. In DJ de 30/04/1964, p.705.

Primeira Turma. Recurso Extraordinário 75680/GO. Relator Min. Luiz Galotti.

Julgamento em 02/03/1973. In DJ de 13/04/1973, p. 2393.

Recurso Extraordinário 90910/PR. Relator Min. Xavier de Albuquerque.

Julgamento em 21/10/1980. In DJ de 14/11/1980, p. 9492.

Recurso Extraordinário 95381/PR. Relator Min. Décio Miranda.

Julgamento em 14/12/1984. In DJ de 19/04/1985, p. 5457.

FARIA, Antônio Bento de. Direito Comercial - Parte Primeira. Rio de Janeiro: A. Coelho Branco Editor, 1948, v. 2.

FERREIRA, Waldemar. Tratado de Direito Comercial. São Paulo: Saraiva, 1961, v. 3.

MENDONÇA, José Xavier Carvalho de. Tratado de Direito Comercial Brasileiro. 2.ed. Rio de Janeiro: Freitas Bastos, 1933, Livro II, v. III.

PEIXOTO, Carlos Fulgêncio da Cunha. As Sociedades por Quotas de Responsabilidade Limitada. Rio de Janeiro: Forense, 1956, v. 1.

REQUIÃO, Rubens. Curso de Direito Comercial. 33.ed. São Paulo: Saraiva, 2014, v.1 